\title{
(2) The Effects of Risk Management System on aße Financial Performance of Commercial Banks in Reserch House Rwanda: A Case of Cogebanque Ltd.
}

\author{
Mireille Hitimana $^{1}$, Julius Warren Kule ${ }^{2 *}$, Peter Mbabazi Mbabazize ${ }^{3}$ \\ ${ }^{1}$ Department of Business Administration, Jomo Kenyatta University of Agriculture and Technology, Kigali, RWANDA \\ ${ }^{2}$ Head of Department, Department of Management and Social Sciences, Jomo Kenyatta University of Agriculture and Technology, Kigali, \\ RWANDA \\ ${ }^{3}$ Lecturer, Department of Business Administration, Jomo Kenyatta University of Agriculture and Technology, Kigali, RWANDA
}

*E-mail for correspondence: kulewarren@gmail.com

Received: Apr 15, 2016; $\quad$ Accepted: May 30, 2016;

Published: Sep 08, 2016

Source of Support: Nil

No Conflict of Interest: Declared

\begin{abstract}
This research study entitled an Assessment of the Effect of Risk Management System on Financial Performance of Commercial Banks in Rwanda aimed at assessing risk factors that performance of commercial banks like credit risk, embezzlement, theft and among others. Three specific objectives were formulated namely; to analyze the effect of directive control system on Financial Performance of Cogebanque Ltd; to establish the effect of preventive control system on Financial Performance of Cogebanque Ltd; to examine the effect of detective control system on Financial Performance of Cogebanque Ltd. The study examined risk management system and financial performances in Cogebanque Ltd located in Kigali City for a period of four years from 2011-2014. The study used descriptive design. A sample size of 40 staff of Cogebanque Ltd, participated in the study. SPSS software (version 22) was used to process the data and analysis were made by use of frequency/percentages, mean and standard deviation. The relationship between the variables was established by use of Pearsons correlation. The study established that different risk management systems which consist of directive control system, preventive control system and detective control system. The study revealed that risk management system has improved Cogebanque bank's return on investment, profitability, liquidity, return asset and return on equity and loan returns by $72.7 \%$.
\end{abstract}

Keywords: Risk Management, Internal Control Systems, Financial Performance, Commercial Banks, Rwanda

\section{INTRODUCTION}

The world over, the Financial sector has become the most important sector in promoting economic growth and development around the globe. To maintain its relevance, it requires innovativeness to meet the rising demand for financial services. As a result, financial products have increased, operational borders have expanded, and new financial markets have emerged. These developments have increased and diversified the risks that the banking sector has to manage (Daniel, 1999). The global financial crisis highlighted the importance of well-functioning and healthy banking sector for macro stability (Chance, 2004). One of the main reasons for banking failures is poor risk management system which resulted in major financial loss and even bankruptcy to financial institutions across the globe. The lack of an internal control system which is to keep the risks under control or major break downs within an existing internal control system poses a threat to the success of the banking sector (Manasseh, 2004).
Internal control system allows banks to foresee potential problems which may cause financial losses and thereby prevent or minimize any future losses. Researches on the causes of bank failures mainly concluded that an efficient and effective internal control system might prevent financial cost around the world and instead promote their financial performance (Merton, 1993).

The main focus of risk management has mainly been on controlling and for regulatory compliance, as opposed to enhancing financial performance (Banks, 2004).

However, risk management often leads to enhanced financial performance as regulatory compliance and control of risks enables the organization to save on costs. Banks (2004) further suggests that by risks, the managers are able to increase the value of a firm through ensuring continued profitability of the firm. Standard and Poor's (2013) identifies poor liquidity management, underpricing and under-reserving, a high tolerance for 
investment risk, management and governance issues, difficulties related to rapid growth and/or expansion into non-core activities as main causes of financial distress and failure in banking institutions. It is important that these factors be managed efficiently by banking institutions, to avoid financial failure and bankruptcy to the firm. Babbel and Santomero (1996) note that bankers should assess the various types of risks they are exposed to and devise ways of effectively managing them. They further suggest that bankers should accept and manage at firm level, only those risks that are uniquely a part of their services.

Stulz (1984) suggested that risk management is a viable economic reason why firm managers, might concern themselves with both the expected profit and the distribution of firm returns around their expected value, hence providing a rationale for aligning firm objective functions to avoid risk.

Like other financial institutions around the world even financial institutions in Rwanda is affected by the crisis and even up to date some commercial Banks are faced by various risks which is affecting their performance. This has made commercial Banks to merge or even sell of their shares to compete favorably with other commercial Banks. For example Commercial Bank of Rwanda (BCR) merged and changed its name to I \& $\mathrm{M}$ bank which is believed to be due to the various risks the bank was exposed to.

COGEBANQUE was created by domestic Investors and started its activities in 1999 at Kacyiru (TELECOM HOUSE) with one branch located at its Headquarter. In 2000 the second branch was opened in the Kigali. currently the banks has 19 branches country-wide. At the beginning COGEBANQUE started with 665 million of Rwandan francs, to promote competition among commercial banks, BNR (National Bank of Rwanda) decided to increase the minimum of share capital from 1.5 billion in 2001, 3billion between 2002 and 2006, preceded by 5 billion in 2008. To achieve the BNR demand, COGEBANQUE made recourse to the foreign investors namely (Shorecap International/USA, Bio/Belgique et AfricInvest/Tunisie); and ceded $40 \%$ of its shares. After the divestment of these shareholders in December 2012 (Shorecap) and March 2014 (Bio and AfricInvest). Currently, the Bank is $100 \%$ locally owned with a RSSB(30\%) and $70 \%$ of the shares are held by institutions and individuals, initial promoters of COGEBANQUE. COGEBANQUE has got various risk management strategies in place to promote organization performance. The strategies range from direct control, preventive control and detective control which involve various activities performed by the board of directors, senior managers, auditors and operational managers basing on the policy, rules and regulations guiding the Bank operations.

\section{Statement of the Problem}

The past decade has seen dramatic losses in the banking industry around the world, banks that had been performing well suddenly announced large losses due to credit exposures that turned sour, interest rate positions taken, or derivative exposures that may or may not have been assumed to hedge balance sheet risk (World Bank, 2012).

Hakim and Neaime (2001) tried to examine the effect of liquidity, credit, and capital on bank performance in the banks of Egypt and Lebanon; they found that there was a sound risk management actions and application of these banks rules and laws. Hosna Manzura and Juanjuan (2009) found that Non-performing loans indicator affected on profitability as measured by (ROE) more than capital adequacy ratio, and the effect of credit risk management on profitability was not the same for all the banks included in their study.

Njanike (2009) found that the absence of effective credit risk management led to the occurrence of the banking crisis, and inadequate risk management systems caused the financial crisis. Aruwa and Musa (2012) investigated the effect of the credit risk, and other risk components on the banks' financial performance. They found a strong relationship between risk components and the banks' financial performance. In the early 2000s, Rwanda experienced liquidity crisis that highlighted the limitations of its liquidity regulation and led to the redesign of the regulatory framework. With the new regulatory framework in place, some banks are still making losses; others have closed or merged with other banks for efficient operations. For example it is believed that Commercial Bank of Rwanda (BCR) was acquired by I \& M bank due to risk exposure (Rwangobwa, 2014). Although studies have been conducted on risk management and financial performance, it still remains unclear as to why banks with sound risk management practices and risk management knowledge still experience performance challenges.

The above background informed the basis for this study. Specific Objectives of the study are:

- To analyze the effect of Directive Control System on Financial Performance of Cogebanque Ltd

- To establish the effect of Preventive Control System on Financial Performance of Cogebanque Ltd

- To examine the effect of Detective Control System on Financial Performance of Cogebanque Ltd

\section{ReseARCH Methodology}

\section{Research design}

The study adopted descriptive design based on qualitative and quantitative approaches. The target population was 40 staff working with Cogebanque Ltd under Internal audit, risk management \& compliance, credit department, and Finance units. Since the population was small, a census of the population was captured as the sample size. 


\section{Data collection and analysis}

A questionnaire and documentary review were used to collect. Frequencies, percentages, mean and standard deviation were the major descriptive statistics while Pearson correlation was used established co-relational relationship between the independent variable and dependent variables.

\section{REsults AND Discussions}

Documentary review focused on the period 2011- 2014, and the figures were used for comparison between the years.

A total of 40 questionnaires were distributed but only 31 were returned. Data analysis was therefore based on 31 respondents.

\section{Effect of Directive Control System on financial Performance of Cogebanque Ltd}

Analysis below shows the effect of Directive Control System on financial Performance of Cogebanque Ltd Assessing Directive Control System of Cogebanque Ltd

Table 1 shows the respondents perception on the Directive Control System of Cogebanque

Table 1: Respondents view on Directive Control System in Cogebanque Ltd

\begin{tabular}{|l|c|c|c|}
\hline $\begin{array}{l}\text { Directive Control System } \\
\text { of Cogebanque Ltd }\end{array}$ & Mean & $\begin{array}{c}\text { Std. } \\
\text { Deviation }\end{array}$ & Comments \\
\hline $\begin{array}{l}\text { Top management ensures that } \\
\text { rules, policies and procedures in } \\
\text { Cogebanque is followed }\end{array}$ & .5161 & .56985 & $\begin{array}{l}\text { Very strong } \\
\text { heterogeneity }\end{array}$ \\
\hline $\begin{array}{l}\text { Staffs performance is regularly } \\
\text { reviewed according to the policy }\end{array}$ & 4.5484 & .62390 & $\begin{array}{l}\text { Very strong } \\
\text { heterogeneity }\end{array}$ \\
\hline $\begin{array}{l}\text { Assets are well protected and } \\
\text { safe guarded as stipulated in the } \\
\text { bank policy }\end{array}$ & 4.4839 & .62562 & $\begin{array}{c}\text { Strong } \\
\text { heterogeneity }\end{array}$ \\
\hline $\begin{array}{l}\text { The bank practices segregation of } \\
\text { duties stated in the policy and } \\
\text { procedures }\end{array}$ & 4.5161 & .56985 & $\begin{array}{l}\text { Very strong } \\
\text { heterogeneity }\end{array}$ \\
\hline $\begin{array}{l}\text { Information system is well } \\
\text { protected through different } \\
\text { security measures design in the } \\
\text { security policy }\end{array}$ & 4.4839 & .56985 & $\begin{array}{c}\text { Strong } \\
\text { heterogeneity }\end{array}$ \\
\hline Valid N (list wise) & $\mathbf{3 1}$ & & \\
\hline
\end{tabular}

Source: Primary data, 2015

Table 1 shows the respondents perception on the Directive Control System of Cogebanque Ltd and their responses were analyzed in details as below; Top management ensures that rules, policies and procedures in Cogebanque Ltd are followed: This was indicated by a Very strong mean of 4.5161 and heterogeneity standard deviation of .56985 . Furthermore, the research wanted to ascertain whether staffs performance is reviewed regularly according to the policy: This was indicated by a Very strong mean of 4.5484 and heterogeneity standard deviation of .62390 .

In assessing whether assets are well protected and safe guarded as stipulated in the bank policy, a Strong mean of 4.4839 was indicated and heterogeneity standard deviation of .62562.
The bank practices segregation of duties stated in the policy and procedures: This was indicated by a Very strong mean of 4.5161 and heterogeneity standard deviation of .56985 . Information system is well protected through different security measures design in the security policy: This was indicated by a Strong mean of 4.4839 and heterogeneity standard deviation of .56985 .

Table 2: Effect of Directive Control System on financial performance of Cogebanque Ltd

\begin{tabular}{|l|l|c|c|}
\hline $\begin{array}{l}\text { Effect of Directive Control System } \\
\text { on financial performance }\end{array}$ & Mean & $\begin{array}{c}\text { Std. } \\
\text { Deviation }\end{array}$ & Comments \\
\hline $\begin{array}{l}\text { Directive Control System has } \\
\text { improved on Cogebanque } \\
\text { return on investment }\end{array}$ & 4.4516 & .50588 & $\begin{array}{c}\text { Strong } \\
\text { heterogeneity }\end{array}$ \\
\hline $\begin{array}{l}\text { Directive Control System has } \\
\text { improved on Cogebanque } \\
\text { profitability }\end{array}$ & 4.3871 & .49514 & $\begin{array}{c}\text { Strong } \\
\text { homogeneity }\end{array}$ \\
\hline $\begin{array}{l}\text { Directive Control System has } \\
\text { improved on Cogebanque liquidity }\end{array}$ & 4.4516 & .50588 & $\begin{array}{c}\text { Strong } \\
\text { heterogeneity }\end{array}$ \\
\hline $\begin{array}{l}\text { Directive Control System has } \\
\text { improved on Cogebanque } \\
\text { equity and loan returns }\end{array}$ & 4.2581 & .44480 & $\begin{array}{c}\text { Strong } \\
\text { homogeneity }\end{array}$ \\
\hline $\begin{array}{l}\text { Directive Control System has } \\
\text { improved on Cogebanque } \\
\text { return on asset }\end{array}$ & 4.2903 & .46141 & $\begin{array}{c}\text { Strong } \\
\text { homogeneity }\end{array}$ \\
\hline Valid N (list wise) & 31 & & \\
\hline
\end{tabular}

Source: Primary data, 2015

Table 2 shows the respondents perception on the effect of directive Control System on financial performance of Cogebanque Ltd and their responses were analyzed in details as below; Directive Control System has improved on Cogebanque return on investment: This was indicated by a Strong mean of 4.4516 and heterogeneity standard deviation of .50588. Directive Control System has improved on Cogebanque profitability: This was indicated by a Strong mean of 4.3871 and homogeneity standard deviation of .49514. This implies that Directive Control System has improved on Cogebanque profitability. Directive Control System has improved on Cogebanque liquidity: This was indicated by a Strong mean of 4.4516 and heterogeneity standard deviation of .50588. This implies that Directive Control System has improved on Cogebanque liquidity. Directive Control System has improved on Cogebanque equity and loan returns: This was indicated by a Strong mean of 4.2581 and homogeneity standard deviation of .44480. This implies that Directive Control System has improved on Cogebanque equity and loan returns. Directive Control System has improved on Cogebanque return on asset: This was indicated by a Strong mean of 4.2903 and homogeneity standard deviation of .46141. This implies that Directive Control System has improved on Cogebanque return on asset.

\section{Relationship between Directive Control System and financial performance}

Table 3 shows the relationship between Directive Control System and financial performance in Cogebanque Ltd 
Table 3: Relationship between Directive Control System and Financial Performance

\begin{tabular}{|c|c|c|c|}
\hline \multicolumn{2}{|l|}{ Relationship } & $\begin{array}{c}\text { Directive } \\
\text { control system }\end{array}$ & $\begin{array}{c}\text { Financial } \\
\text { performance }\end{array}$ \\
\hline \multirow{3}{*}{$\begin{array}{l}\text { Directive } \\
\text { Control } \\
\text { System } \\
\end{array}$} & Pearson Correlation & 1 & $.769^{* *}$ \\
\hline & Sig. (2-tailed) & & .000 \\
\hline & $\mathrm{N}$ & 31 & 31 \\
\hline \multirow{3}{*}{$\begin{array}{l}\text { Financial } \\
\text { performance }\end{array}$} & Pearson Correlation & $.769^{* *}$ & 1 \\
\hline & Sig. (2-tailed) & .000 & \\
\hline & $\mathrm{N}$ & 31 & 31 \\
\hline
\end{tabular}

Table 3 is shows the relationship between Directive Control System and Financial performance in Cogebanque whereby the respondents $\mathrm{N}$ is 31 and the significant level is 0.01 , the results indicate that independent variable has positive high correlation to dependent variable equal to $.769^{* * *}$ and the p-value is .000 which is less than 0.01 and when p-value is less than significant level, therefore researchers conclude that variables are correlated and null hypothesis is rejected and remains with alternative hypothesis. This means that there is a significant relationship between Directive Control System and financial performance in Cogebanque. In conclusion therefore, Directive Control System contributes to positive financial performance in Cogebanque Ltd of this research project by $76.9 \%$.

\section{Effect of Preventive Control System on financial Performance of Cogebanque Ltd}

This sections analyses Preventive Control System and its effect on Cogebanque Ltd

\section{Assessing Preventive Control System of Cogebanque Ltd}

Table 4 shows the respondents perception on the Preventive Control System of Cogebanque Ltd

Table 4: Respondents view on Preventive Control System in Cogebanque $L t d$

\begin{tabular}{|l|c|c|c|}
\hline $\begin{array}{l}\text { Preventive Control System of } \\
\text { Cogebanque Ltd }\end{array}$ & Mean & $\begin{array}{c}\text { Std. } \\
\text { Deviation }\end{array}$ & Comments \\
\hline $\begin{array}{l}\text { Management ensures that there } \\
\text { is separation of duties to make } \\
\text { staffs do defined activities }\end{array}$ & 4.4194 & .50161 & $\begin{array}{c}\text { Strong } \\
\text { heterogeneity }\end{array}$ \\
\hline $\begin{array}{l}\text { Management ensures that there } \\
\text { is proper authorization and } \\
\text { approval in the bank avoid bank } \\
\text { from being involved in risks }\end{array}$ & 4.4516 & .50588 & $\begin{array}{c}\text { Strong } \\
\text { heterogeneity }\end{array}$ \\
\hline $\begin{array}{l}\text { Management ensures that there } \\
\text { is adequate documentation of } \\
\text { all transactions in the bank }\end{array}$ & 4.3871 & .49514 & $\begin{array}{c}\text { Strong } \\
\text { homogeneity }\end{array}$ \\
\hline $\begin{array}{l}\text { Management ensures that there } \\
\text { is physical control over assets of } \\
\text { the bank }\end{array}$ & 4.4194 & .50161 & $\begin{array}{c}\text { Strong } \\
\text { heterogeneity }\end{array}$ \\
\hline Valid N (list wise) & 31 & & \\
\hline
\end{tabular}

Source: Primary data, 2015

Table 4 shows the respondents perception on the Preventive Control System of Cogebanque Ltd and their responses were analyzed in details as below:
Management ensures that there is separation of duties to make staff perform defined activities: This was indicated by a Strong mean of 4.4194 and heterogeneity standard deviation of .50161. This implies that Management ensures that there is separation of duties to make staffs do defined activities. Management ensures that there is proper authorization and approval in the bank to avoid bank from being involved in risks: This was indicated by a Strong mean of 4.4516 and heterogeneity standard deviation of .50588. This implies that Management ensures that there is proper authorization and approval in the bank avoid bank from being involved in risks. Management ensures that there is adequate documentation of all transactions in the bank: This was indicated by a Strong mean of 4.3871 and homogeneity standard deviation of .49514. This implies that Management ensures that there is adequate documentation of all transactions in the bank. Management ensures that there is physical control over assets of the bank: This was indicated by a Strong mean of 4.4194 and heterogeneity standard deviation of .50161. This implies that Management ensures that there is physical control over assets of the bank.

Table 5: Effect of Preventive Control System on financial performance of Cogebanque Ltd

\begin{tabular}{|l|c|c|c|}
\hline $\begin{array}{l}\text { Effect of Preventive Control } \\
\text { System on financial performance }\end{array}$ & Mean & $\begin{array}{c}\text { Std. } \\
\text { Deviation }\end{array}$ & Comments \\
\hline $\begin{array}{l}\text { Preventive control system has } \\
\text { improved on Cogebanque } \\
\text { return on investment }\end{array}$ & 4.4194 & .56416 & $\begin{array}{c}\text { Strong } \\
\text { heterogeneity }\end{array}$ \\
\hline $\begin{array}{l}\text { Preventive control system has } \\
\text { improved on Cogebanque } \\
\text { profitability }\end{array}$ & 4.3871 & .61522 & $\begin{array}{c}\text { Strong } \\
\text { heterogeneity }\end{array}$ \\
\hline $\begin{array}{l}\text { Preventive control system has } \\
\text { improved on Cogebanque } \\
\text { return on asset }\end{array}$ & 4.5161 & .50800 & $\begin{array}{c}\text { Very Strong } \\
\text { heterogeneity }\end{array}$ \\
\hline $\begin{array}{l}\text { Preventive control system has } \\
\text { improved on Cogebanque } \\
\text { equity and loan return }\end{array}$ & 4.5806 & .50161 & $\begin{array}{c}\text { Very Strong } \\
\text { heterogeneity }\end{array}$ \\
\hline $\begin{array}{l}\text { Preventive control system has } \\
\text { improved on Cogebanque } \\
\text { liquidity }\end{array}$ & 4.5484 & .56796 & $\begin{array}{c}\text { Very Strong } \\
\text { heterogeneity }\end{array}$ \\
\hline Valid N (list wise) & $\mathbf{3 1}$ & & \\
\hline
\end{tabular}

Source: Primary data, 2015

Table 5 shows effect of Preventive Control System on financial performance of Cogebanque Ltd and their responses were analyzed in details as below:

Preventive Control System has improved on Cogebanque return on investment: This was indicated by a Strong mean of 4.4194 and heterogeneity standard deviation of .56416.

This implies that Preventive Control System has improved on Cogebanque return on investment as seen in the financial statement analysis in section 15. Preventive Control System has improved on Cogebanque profitability: This was indicated by a Strong mean of 4.3871 and heterogeneity standard deviation of .61522 . This implies that Preventive Control System has improved on Cogebanque profitability. Preventive 
Control System has improved on Cogebanque return on asset: This was indicated by a very strong mean of 4.5161 and heterogeneity standard deviation of .50800. This implies that Preventive Control System has improved on Cogebanque return on asset.

Preventive Control System has improved on Cogebanque equity and loan return: This was indicated by a Very strong mean of 4.5806 and heterogeneity standard deviation of .50161. This implies that Preventive control system has improved on Cogebanque equity and loan return. Preventive Control System has improved on Cogebanque liquidity: This was indicated by a Very strong mean of 4.5484 and heterogeneity standard deviation of .56796. This implies that Preventive control system has improved on Cogebanque liquidity.

\section{Relationship between Preventive Control System and} financial performance

Table 6 shows the relationship between preventive Control System and financial performance in Cogebanque Ltd

Table 6: Relationship between Preventive Control System and financial performance

\begin{tabular}{|c|c|c|c|}
\hline \multicolumn{2}{|l|}{ Relationship } & $\begin{array}{c}\begin{array}{c}\text { Preventive } \\
\text { control system }\end{array} \\
\end{array}$ & $\begin{array}{c}\text { Financial } \\
\text { performance }\end{array}$ \\
\hline \multirow{3}{*}{\begin{tabular}{|l|} 
Preventive \\
control \\
system
\end{tabular}} & Pearson Correlation & 1 & $.656^{* *}$ \\
\hline & Sig. (2-tailed) & & .000 \\
\hline & $\mathrm{N}$ & 31 & 31 \\
\hline \multirow{3}{*}{$\begin{array}{l}\text { Financial } \\
\text { performance }\end{array}$} & Pearson Correlation & $.656^{* *}$ & 1 \\
\hline & Sig. (2-tailed) & .000 & \\
\hline & $\mathrm{N}$ & 31 & 31 \\
\hline
\end{tabular}

Table 6 shows the relationship between Preventive Control System and Financial performance in Cogebanque whereby the respondents $\mathrm{N}$ is 31 and the significant level is 0.01 , the results indicate that independent variable has positive high correlation to dependent variable equal to $.656^{* *}$ and the $p$-value is .000 which is less than 0.01 and when $p$-value is less than significant level, therefore researchers conclude that variables are correlated and null hypothesis is rejected and remains with alternative hypothesis. This means that there is a significant relationship between Preventive control system and financial performance in Cogebanque Ltd.

In conclusion therefore, Preventive Control System contributes to positive financial performance in Cogebanque Ltd of this research project by $65.6 \%$.

\section{Effect of Detective Controls on Financial Performance of Cogebanque Ltd}

This section analyses the Detective Controls System and its effect on financial performance of Cogebanque Ltd

\section{Assessing Detective Controls System in Cogebanque Ltd}

Table 7 shows the respondents perception on the Detective Controls System on financial performance of Cogebanque Ltd
Table 7: Respondents view on Detective Controls System in Cogebanque Ltd

\begin{tabular}{|l|c|c|c|}
\hline $\begin{array}{l}\text { Detective Controls System of } \\
\text { Cogebanque Ltd }\end{array}$ & Mean & $\begin{array}{c}\text { Std. } \\
\text { Deviation }\end{array}$ & Comments \\
\hline $\begin{array}{l}\text { Internal audit detects loop } \\
\text { holes in the policy }\end{array}$ & 4.1290 & .42755 & $\begin{array}{c}\text { Strong } \\
\text { homogeneity }\end{array}$ \\
\hline $\begin{array}{l}\text { The bank ensures that theft of } \\
\text { bank asset is detected }\end{array}$ & 4.4839 & .56985 & $\begin{array}{c}\text { Strong } \\
\text { heterogeneity }\end{array}$ \\
\hline $\begin{array}{l}\text { The bank ensures that errors } \\
\text { performed in the bank is } \\
\text { detected }\end{array}$ & 4.4194 & .50161 & $\begin{array}{c}\text { Strong } \\
\text { heterogeneity }\end{array}$ \\
\hline $\begin{array}{l}\text { Management ensures that } \\
\text { there is compliancy with bank } \\
\text { policy and procedures }\end{array}$ & 4.3226 & .54081 & $\begin{array}{c}\text { Strong } \\
\text { heterogeneity }\end{array}$ \\
\hline Valid N (list wise) & 31 & & \\
\hline
\end{tabular}

Source: Primary data, 2015

Table 7 shows the respondents' perception on the detective controls system on performance of Cogebanque Ltd and their responses were as analyzed in details below; Internal audit detects loop holes in the policy: This was indicated by a Strong mean of 4.1290 and homogeneity standard deviation of .42755. The bank ensures that theft of bank asset is detected: This was indicated by a Strong mean of 4.4839 and heterogeneity standard deviation of .56985. The bank ensures that errors performed in the bank are detected: This was indicated by a Strong mean of 4.4194 and heterogeneity standard deviation of .50161. Management ensures that there is compliancy with bank policy and procedures: This was indicated by a Strong mean of 4.3226 and heterogeneity standard deviation of .54081 .

Table 8: Effect of Detective Controls on financial performance of Cogebanque $L t d$

\begin{tabular}{|l|l|c|c|}
\hline $\begin{array}{l}\text { Effect of Detective Controls } \\
\text { on financial performance }\end{array}$ & Mean & $\begin{array}{c}\text { Std. } \\
\text { Deviation }\end{array}$ & Comments \\
\hline $\begin{array}{l}\text { Detective Controls System } \\
\text { improved on Cogebanque } \\
\text { return on investment }\end{array}$ & 4.3871 & .71542 & $\begin{array}{c}\text { Strong } \\
\text { heterogeneity }\end{array}$ \\
\hline $\begin{array}{l}\text { Detective Controls System } \\
\text { improved on Cogebanque } \\
\text { profitability }\end{array}$ & 4.4194 & .67202 & $\begin{array}{c}\text { Strong } \\
\text { heterogeneity }\end{array}$ \\
\hline $\begin{array}{l}\text { Detective Controls System } \\
\text { improved on Cogebanque } \\
\text { return on asset }\end{array}$ & 4.2903 & .58842 & $\begin{array}{c}\text { Strong } \\
\text { heterogeneity }\end{array}$ \\
\hline $\begin{array}{l}\text { Detective Controls System } \\
\text { improved on Cogebanque } \\
\text { equity and loan return }\end{array}$ & 4.3226 & .65254 & $\begin{array}{c}\text { Strong } \\
\text { heterogeneity }\end{array}$ \\
\hline $\begin{array}{l}\text { Detective Controls System } \\
\text { improved on Cogebanque } \\
\text { liquidity }\end{array}$ & 4.3548 & .75491 & $\begin{array}{c}\text { Strong } \\
\text { heterogeneity }\end{array}$ \\
\hline Valid N (list wise) & 31 & & \\
\hline
\end{tabular}

Source: Primary data, 2015

Table 8 shows the effect of Detective Controls on financial performance of Cogebanque Ltd and their responses were analyzed in details below; Detective Controls System improved on Cogebanque return on investment: This was indicated by a Strong mean of 4.3871 and heterogeneity standard deviation of .71542. This implies that Detective Controls System improved on Cogebanque return on investment. Detective Controls System improved on Cogebanque profitability: This was indicated by a Strong mean of 4.4194 and heterogeneity standard deviation of .67202 . This implies that Detective 
Controls System improved on Cogebanque profitability. Detective Controls System improved on Cogebanque return on asset: This was indicated by a Strong mean of 4.2903 and heterogeneity standard deviation of .58842 . This implies that Detective controls system improved on Cogebanque return on asset. Detective Controls System improved on Cogebanque equity and loan return: This was indicated by a Strong mean of 4.3226 and heterogeneity standard deviation of .65254. This implies that Detective Controls System improved on Cogebanque equity and loan return. Detective Controls System improved on Cogebanque liquidity: This was indicated by a Strong mean of 4.3548 and heterogeneity standard deviation of .75491. This implies that Detective Controls System improved on Cogebanque liquidity.

Table 9: Relationship between Detective Control System and financial performance

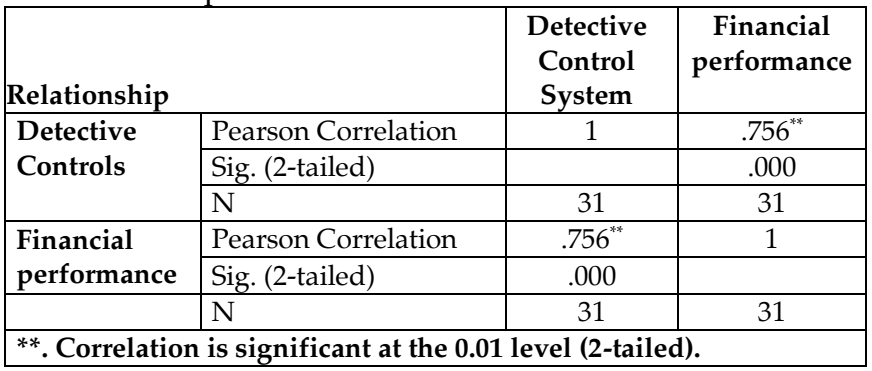

Table 9 is giving the relationship between Detective Control System and Financial performance in Cogebanque whereby the respondents $\mathrm{N}$ is 31 and the significant level is 0.01 , the results indicate that independent variable has positive high correlation to dependent variable equal to $.756^{* *}$ and the $\mathrm{p}$ value is .000 which is less than 0.01 and when $p$-value is less than significant level, therefore researchers conclude that variables are correlated and null hypothesis is rejected and remains with alternative hypothesis. This means that there is a significant relationship between Detective control system and financial performance in Cogebanque Ltd.

In conclusion therefore, Detective Control System contributes to positive financial performance in Cogebanque Ltd of this research project by $75.6 \%$.

\section{Relationship between Risk Management System and} financial performance

Table 10 shows the relationship between Risk Management System and financial performance in Cogebanque Ltd

Table 10: Relationship between Risk Management System and financial performance

\begin{tabular}{|c|c|c|c|}
\hline \multicolumn{2}{|l|}{ Relationship } & $\begin{array}{c}\text { Risk } \\
\text { Management } \\
\text { System }\end{array}$ & $\begin{array}{c}\text { Financial } \\
\text { performance }\end{array}$ \\
\hline \multirow{3}{*}{$\begin{array}{l}\text { Risk } \\
\text { Management } \\
\text { System } \\
\end{array}$} & Pearson Correlation & 1 & $.727^{* *}$ \\
\hline & Sig. (2-tailed) & & .000 \\
\hline & $\mathrm{N}$ & 31 & 31 \\
\hline \multirow{3}{*}{$\begin{array}{l}\begin{array}{l}\text { Financial } \\
\text { performance }\end{array} \\
\end{array}$} & Pearson Correlation & $.727^{* *}$ & 1 \\
\hline & Sig. (2-tailed) & .000 & \\
\hline & $\mathrm{N}$ & 31 & 31 \\
\hline
\end{tabular}

Table 10 shows the relationship between Risk Management System and Financial performance in Cogebanque whereby the respondents $\mathrm{N}$ is 31 and the significant level is 0.01 , the results indicate that independent variable has positive high correlation to dependent variable equal to $.727^{* *}$ and the $p$-value is .000 which is less than 0.01 and when p-value is less than significant level, therefore researchers conclude that variables are correlated and null hypothesis is rejected and remains with alternative hypothesis. This means that there is a significant relationship between Risk Management System and financial performance in Cogebanque. In conclusion therefore, Risk Management System contributes to positive financial performance in Cogebanque Ltd of this research project by $72.7 \%$.

\section{SUMMARY OF CONTROL SYSTEM}

This section provides summary on directive control system, preventive control system and detective control system on financial performance

\section{Effect of Directive Control System on Financial Performance of Cogebanque Ltd}

In the findings, it was established that Directive Control Systems like rules, policies and procedures on review of Staffs performance, asset management, segregation of duties, information system security policy have improved Cogebanque return on investment, profitability, liquidity, return asset and return on equity and loan returns by $76.9 \%$.

\section{Effect of Preventive Control System on Financial Performance of Cogebanque Ltd}

Further, the findings revealed that Preventive Control Systems such separation of duties to make staffs perform defined activities, proper authorization and approval in the bank avoid bank from being involved in risks, adequate documentation of all transactions in the bank and physical control over assets of the bank improved Cogebanque return on investment, profitability, return on asset, equity and loan return and liquidity by $65.6 \%$.

Effect of Detective Control System on Financial Performance of Cogebanque Ltd

The findings revealed that detective control system and internal audit help in detecting loop holes in the policy, ensure that theft of bank assets is detected, errors performed in the bank are detected. Further, compliancy with bank policy and procedures have improved Cogebanque return on investment, profitability, return on asset, equity and loan return and liquidity by $75.6 \%$.

\section{CONCLUSION}

In conclusion it can be stated that Directive Control provides rules, policies and procedures on review of staff performance, asset management, segregation of duties, information system security policy. Preventive Control System enables separation of duties. This enables staff to perform defined activities, 
ensure proper authorization and approval in the bank to avoid bank risks. Further adequate documentation of all transactions in the bank and physical control over assets of the bank enhance security and minimization of risk. The existence of risk management system has improved Cogebanque's return on investment, profitability, liquidity, return asset and return on equity and loan returns by $72.7 \%$.

\section{RECOMMENDATIONS}

The study recommends the following;

- Assessment of the adequacy of the internal control process and its compliance with established policies and procedures has to be performed by the internal audit (inspection) unit and this will solve the issue of hacking into the system.

- Efficiency of the internal control process should be evaluated periodically. Such evaluation should be done by authorized personnel through selfassessments when personnel responsible for a particular function determine the effectiveness of controls for their activities.

- All levels of review must be adequately documented and reported on a timely basis to the appropriate level of management. This will solve the issue of complacency on the part of supervisors while performing their duties.

\section{REFERENCES}

Amundo, A and Eno L, I (2009). Evaluation of Internal Control Systems: International Research Journal of Finance and Economics. Vol 29, pp 128-130

Angbazo, L. (1997), "Commercial Bank Net Interest Margins, Default Risk, Interest Rate Risk, and Off-Balance Sheet Banking", Journal of Banking and Finance, Vol. 21, pp. 55-87.

Aruwa, S.A. and Musa, O.A. (2014). Risk components and the financial performance of deposit money in Nigeria, International Journal of Social Sciences and Entrepreneurship, 1 (11), pp. 1-8.

Association of Chartered Certified Accountants (2010), Audit and assurance study text.BPP Learning Media Ltd, BPP House, Aldine Place

Babbel, D.F. \& Santomero, A.M. (1996). Risk Management by Insurers: An Analysis of the Process, Working Paper\#96-16, Wharton Financial Institutions Center,

Banks, E. (2004). Alternative Risk Transfer: Integrated Risk Management Through Insurance, Re-insurance and the Capital Markets, John Wiley \& Sons Ltd.

Black (1976). Methods and issues in social research. New York: John Wiley \& Sons.

Bonnevie, F. (2003), Risk Management in Banking Financial Services, Advanced International Training Programme.

Bou-Raad, G. (2000), Internal Auditors and a Value-added Approach: The New Business Regime", Managerial Auditing Journal, 15: 182-86.

Bruner, C. M. (2010). Corporate governance reform in a time of crisis. The Journal of Corporate Law, 36(2), 309-341.

Chance, D. M (2004), an introduction to Derivatives $\mathcal{E}$ Risk management. Thomson, South western Louisiana State University
Chester, S. (2003), An introduction and Discussion on Risk Management, CIMA Publishing, London

Chorafas, D. N. (2008), Risk Accounting and Risk Management for Accountants, CIMA Publication, Elsevier, United Kingdom

Christopher, L. C (2001), the risk management process Business strategy and tactics. John Wiley \& Sons, inc. New York, Chichester, Brisbane. Singapore. Toronto.

CIMA Official Terminology (2005), Chartered Institute of Management Accountants, CIMA Publication

Collier, P. M., Berry, A. J. and Burkey, G. T. (2007), Risk and Management Accounting: Best Practice Guidelines for Enterprise-wide Internal Control Procedures, CIMA Publishing, London

Committee of Sponsoring Organization of the Tread way Commission [COSO] (2005), Internal Control Integrated Framework, Committee of Sponsoring Organization of the Treadway Commission, New York.

Committee of Sponsoring Organizations of the Treadway Commission [COSO] (2009), Enterprise Risk ManagementIntegrated Framework, AICPA, New York

Cornell, B. Shapiro, A.C. (1987),“Corporate Stakeholders and Corporate Finance", Financial Management, Vol.16, pp. 5-14.

COSO (2011), "Enterprise Risk management - integrated framework", Committee of Hooks.

Daniel, E. (1999) Provision of Electronic Banking in the UK and the Republic of Ireland, International Journal of Bank Marketing, Vol. 17, No. 2, pp. 72-82

Dixion, J. R. (1990). The New Performance Challenge Harvard Business Review $6769-78$.

Drzik, J. (2005), "New Directions in Risk Management", Journal of Financial Econometrics, Vol. 1, pp. 26-38.

Faff, R., Nguyen,H. (2002), “On The Determinants of Derivative Usage by Australian Companies", Australian Journal of Management, Vol. 27, No. 1, pp. 1-24.

Fite, D.,P fleiderer, P . (1995), "Should Firms Use Derivatives to Manage Risk? ", in Beaver W ., Parker, G. (Ed.), Risk Management: Problems and Solutions, McGraw-Hill, New York, pp. 61-76

Flesher, L. D (1996), internal auditing standards practices. Florida: The IIA.

Freeman,R. E. (1984), Strategic management: A stakeholder approach, Prentice- Hall, Englewood Cliffs, NJ.

Geczy, C., Minton, B.A., Schrand, C. (1997), "Why Firms Use Derivatives", The Journal of Finance, Vol. 52, No. 4, pp. 1323-1354.

Gleim, I. (2013), Internal audit practices CIA review Part 2 First edition, Gainesville, Gleim publications, Inc.

Hakim, S and Neami, S. (2001), "Performance and Credit Risk in Banking: A Comparative Study of Egypt and Lebanon, ERF Working Paper Series, Working Paper 0137

Holt, M. F. (2006), The Sarbanes-Oxley act: overview and implementation procedures, Elsevier CIMA Publication, Oxford.

Hosna, A. and Manzura, B. and Juajuan, S. (2009). Credit risk management and profitability in commercial banks in Sweden, Master Theses.

IRM, et al., (2002), A Risk Management Standard, AIRMIC, ALARM, IRM, United Kingdom, London.

Jin, Y. ,Jorion, P. (2006), "Firm Value and Hedging: Evidence from US Oil and Gas Producers", The Journal of Finance, Vol. 61, No. 2, pp. 893-919. 
Kaplan, S. E., Schultz, J.J.(1994) Enhancing Communication to Assist in Fraud Prevention and Detection. Auditing: A Journal of Practice and Theory, vol. 13, pp 86-117

Karagiorgos T., Drogalas G., Eleftheriadis, I. \& Christodoulou P.(2010), "Internal audit contribution to efficient risk management" Business Journal, Vol. 2, No 1, pp 6

Kirkpatrick, G. (2009). The corporate governance lessons from the financial crisis. OECD Journal: Financial Market Trends, 2009(1), 61-87.

Klimczak, K. M. (2005), “Corporate Risk Management from Stakeholders' Perspective", TRANS’05, SGH, Warszawa, Poland, pp. 371-380.

Li, P. (2009). How can corporate governance control enterprise's financial risk, The Journal of Finance, Vol. 61, No. 2, pp. 893-919

MacCrimmon, K. R., Wehrung, D. A. (1990), "Characteristics of Risk Taking Executives", Management Science, Vol. 36, No.4, pp. $422-435$

Maheshwari S.N, (2009). Financial statement analysis, $8^{\text {th }}$ edition New Delhi: Sultan Chand \& Sons Educational Publishers.

Manasseh, P.N. (2004), A textbook of principles of auditing, sixth edition, Nairobi Kenya

Mautz, R. K. and Winjum, J. (1981), Criteria for Management Control Systems, Financial Executives Research Foundation, New York.

Mavrodin, D. (2008), Internal Auditing Course-Support, Titu University Publishing house, Bucharest, 2008.

Mayers, D., Smith, C. W. (1987), "Corporate Insurance and the Underinvestment Problem", The Journal of Risk and Insurance,Vol. 54, No. 1, pp. 45-54.

Merton, R.C (1993), Management of Risk in Financial Firms.

Miller,M. H., Modigliani, F.(1958), "The Cost of Capital and the Theory of Investment", American Economic Review,Vol. 48, pp. 261-297.

Millichamp, A.H. (2002). Auditing (9th edition.)

Ministry of Finance and Economic Planning (2009), Ministerial Order $N^{\circ} 002 / 09 / 10 / G P / A$ of 12/02/2009 setting out regulations for internal control and internal audit in government of Rwanda

Mohammed, S. A. (2011), internal audit and risk assessment in Ethiopian public entities. Addis Ababa University, Addis Ababa.

National Bank of Rwanda (2009), Risk Management guidelines for Non-Bank Financial institutions

Njanike, K. (2009). The Impact of Effective Credit Risk Management on Bank Survival, Journal of Financial Regulation and Compliance, Working paper, Bindura University, Zimbabwe.

Nocco., B.W. and Stulz, R. (2006), Enterprise risk management: Theory and practice, Ohio State University working paper
Pagach, D.P. and Warr, R.S (2007), "An Empirical Investigation of the Characteristics of Firms Adopting Enterprise Risk Management

Pickett, S. K .H. (2003), "the Essential Handbook of Internal Auditing", John Wiley and Sons, Ltd Systems

Risk Management Association (2004), Credit Culture: The Foundation of Best Practice. Journal of Banking and Finance Vol.22 Pg 15-17

Rose, P. (2010). Regulating risk by strengthening corporate governance (Public Law and Legal Theory Working Paper No. 130).

Rudasingwa, J. (2006), the role of Internal Audit function in enhancing risk Management in the Rwandan Social security (RSSF). Tshwane University of Technology

Saunders, A. (1999), Credit Risk Management: An Analysis of the process. The Wharton School University of Pennsylvania

Sawyer, B. (2003), "Sawyer's Internal auditing. The practice of Modern Internal Auditing", The Institute of Internal Auditors, $5^{\text {th }}$ edition, ISBN 0-89413-509-0, 120-121

Sawyer, L. \& Vinten, G. (1996), the Manager and the Internal Auditor Partners for Profit, Wiley. Chichester

Schroeck, G. (2002), "Risk Management and Value Creation in Financial Institutions", John Wiley and Sons, Inc

Selim, G. \& McNamee, D. (1999), Risk Management and Internal Auditing relationship: Developing and Validating a model," International Journal of Auditing, 3(3), 159-174

Smith, C. W., Stulz, R. M. (1995), "The Determinants of Firm's Hedging Policies", Journal of Finance and Quantitative Analysis, Vol. 20, No. 4, pp. 391-405.

Stulz, R.M. (1984). Optimal hedging policies. Journal of Financial and Quantitative Analysis, 19, 127-140.

The Institute of Internal Auditors (1999), "Definition of Internal Auditing," The Institute of Internal Auditors, Altamonte Springs, FL

The Institute of Internal Auditors (2004), "International standards for the professional practice of internal auditing," Retrieved from http://www.theiia.org/?doc_id

Tufano,P. (1996),“Who manages risk? An empirical examination of risk management practices in the gold mining industry", The Journal of Finance, Vol. 51, No. 4, pp. 1097-1137.

Vallabhaneni, R. S. (2005), Exam review: internal audit activity's role in governance, risk, and control. Volume 1.New Jersey: John Wiley and Sons, Inc.

Welman, J. C. \& Kruger, S. J. (2001), Research methodology: For Business and Administration Sciences. $2^{\text {nd }}$ edition. Cape Town. Oxford University Press

Williamson, O.E. (1998), "The Institutions of Governance", The AEA Papers and Proceedings, Vol. 88, No.2, pp. 75-79

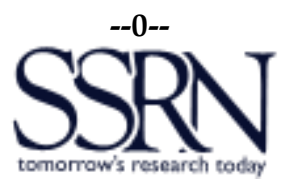

\section{SOCIAL SCIENCE RESEARCH NETWORK 2171 Monroe Avenue, Suite 203, Rochester, NY 14618, USA http://www.ssrn.com/en/}

AJTP Link: http://www.ssrn.com/link/American-Journal-Trade-Policy.html 